\title{
Social Entrepreneurship: Role of Networks in Capturing Opportunities.
}

\author{
Angwi E.Tassang ${ }^{1 *} \quad$ Sayibu Muhideen ${ }^{1} \quad$ Helen Ashu $^{1} \quad$ Beatrice Abosi ${ }^{1} \quad$ Duan Yuzhen ${ }^{2}$ \\ 1.School of Public Affairs, University of Science and Technology of China \\ 2390026 Anhui-Hefei, China \\ 2.Anhui Open University, 230039 Anhui China
}

\begin{abstract}
Social entrepreneurship, an exercise that amalgamates non-profit operations and business values in quest of social impact, has the ability to empower lots of individuals around the world in social problem-solving. This article investigates how managerial ties assist social entrepreneurs in discovering and capturing opportunities for their course. We also look at the moderating effect of centrality on the relationship between the social entrepreneur, managerial ties and opportunity. Drawing a sample from 300 social entrepreneurs, we recorded that, business ties have a more positive effect on opportunity and both degree and betweenness centrality positively moderates this relationship. However, social entrepreneurs are encouraged to establish ties with both government and business because they have different services to offer. But that notwithstanding, they are encouraged to have more business ties to discover and capture opportunities.
\end{abstract}

Keywords: Social Entrepreneurship, government ties, business ties, opportunity capture.

DOI: $10.7176 / \mathrm{JRDM} / 53-06$

Publication date:March $31^{\text {st }} 2019$

\section{Introduction}

The term social entrepreneurship has many definitions attached to it. Social entrepreneurship can be defined, as entrepreneurial activity with an embedded social purpose (Driver, Porter, \& Lawrence, 2012). Social entrepreneurship commences with the organization and formation of social groupings in a small identifiable area with common aims, goals, aspirations, in an attempt of identifying opportunities for members for effective utilization of available resources without parochial selfish interest (El Ebrashi, 2013). The late Greg Dees, father of social entrepreneurship education makes us understand that social entrepreneurship is an activity with an embedded purpose which entails, social entrepreneurs creating public values, pursuing new opportunities, innovating and adapting, acting boldly, leveraging resources they don't control, and exhibiting a strong sense of accountability (Bornstein, David, 2010). "Without an opportunity, there is no entrepreneurship" (Short, J. C., Ketchen Jr, D. J., Shook, C. L., \& Ireland, 2010).

Social entrepreneurs are a group of people who are out to find a solution to a problem (Pozen, 2008). Social entrepreneurs most a times start very small (on a low key) with not often much income (Caliendo \& Kritikos, 2010). This is because their primary objective or main goal is not profit making. Profit making might be a secondary or tertiary objective but never the main goal (Brooks, 2008). Viewed as the heart of entrepreneurship, the ability to capture opportunity is vital to promote new ventures' growth (Austin, Stevenson, \& Wei-Skillern, 2006).

The purpose of this research is to study the effect of business and governmental ties of SE on opportunity capture. Likewise, how degree and between-ness centrality affect the relationship between SE, managerial ties and opportunity capture.

\section{Literature Review}

Though social entrepreneurs usually start on small local efforts, they often target problems that do not only have local expressions but global relevance (Jenvey, 2015), such as waste management, access to water etc. However, suffering from the dangers of originality, new ventures may not possess enough internal resources to capture opportunities (McGrath, 1995). As a result, external resources such as managerial ties are often mobilized to identify and capture opportunities (Peng \& Luo, 2000). Managerial ties refer to political or governmental (formal) and business (informal) ties. Managerial ties are very important to social entrepreneurs in the sense that, they offer them with resources and information which helps them in discovering and capturing opportunities hence a push in a new venture (Strobl, 2014). Managerial ties are commonly perceived as "executives' boundary-spanning activities and their associated interactions with external entities" (Geletkanycz \& Hambrick, 1997). In an evolving economy categorized by an inadequate market structure, official institutions such as ministries, may not make available enough support to new projects (Sheng, Zhou, \& Julie Juan Li, 2011). In this case, managerial ties, especially business ties act as key social capital can help firms to access scarce resources (Li, J. J., Poppo, L., \& Zhou, 2008), manage environmental uncertainties (Li, J. J., \& Zhou, 2010), and improve firm performance.

Scarce resources such as land, capital, and the latest news about industrial planning or relevant policies and 
regulations, all of which may facilitate social entrepreneurs to quickly discover and capture opportunities can be gotten mostly through their political ties (Zheng, Singh, \& Chung, 2017). Government ties alone cannot help social entrepreneurs achieve their goals. Business ties play a very vital role in identifying and capturing opportunities. Business ties often offer some very scarce information about the society and environment which government ties cannot provide (Chen, Chang, \& Lee, 2015), (Zhou, Li, Sheng, \& Shao, 2014). Thus, social entrepreneurs with wide-ranging social networks tend to be more successful at grasping opportunities than those with narrower ones (Nieto \& González-Álvarez, 2016).

Scholars fundamental opinion of entrepreneurship is that opportunities are 'discovered' (Peng, Lee, \& Hong, 2014). This opinion is grounded on a positivist ideology and argues that opportunities are objective certainties that exist in the environment and are "discovered" as a result of the unique characteristics of individual entrepreneur thus risk taken ability (Shane, 2012). Most studies in this area categorize the distinctive elements of the entrepreneurs such as innovation, susceptibility to risk and provocativeness (Suddaby, Bruton, \& Si, 2015), that gives them the ability to see opportunities that most other individuals overlook. More so, capturing opportunities by SE are social constructions that do not exist independently of entrepreneurs' perceptions (Pruthi, 2014). It involves collaborating and building an accord within networks. Entrepreneurial opportunities are ultimately determined, not in an exogenous method by the exterior milieu, but rather in an endogenous way, through the innovative dreams and social ability of the entrepreneur (Ramoglou \& Tsang, 2016). The social entrepreneurial organizations used in this study were seen as organizations who gather and use their managerial ties (networks) to access opportunity.

To crown it all, the centrality or the different levels of positions of the social entrepreneur with its government and business ties, greatly affect the output of the ties to the social entrepreneur. Degree, between-ness or closeness centrality moderates the release of resources and information by managerial ties to social entrepreneurs.

\section{Theoretical Framework}

This research focuses on social entrepreneur's ties which can enable them to recognize an opportunity for themselves. Reasons which, the theory to be used in this research is the Social Network Theory. A network is a link, tool or relationship used by those involved to share information and resources. Networks consist of actors and the connections between those actors. Social network theory views social relations in terms of a network consisting of nodes and ties (Liu, Sidhu, Beacom, \& Valente, 2017). Nodes refer to the individual actors within the network and ties refer to the relationship between these actors (Ghose \& Pettygrove, 2014). On the one hand, Political or government ties are a firm's informal social connections with government officials in various levels of administration (Li, J. J., Poppo, L., \& Zhou, 2008), (Peng \& Luo, 2000). On the other hand, Business ties are a firm's connections with business organizations, and can be represented through relationships with buyers, suppliers, competitors, entrepreneurs, financial institutions, companies and other market collaborators (Li, J. J., Poppo, L., \& Zhou, 2008), (Peng \& Luo, 2000).

The section of the social network theory which we will be using in this study is Centrality. Centrality is very essential for this work because, centrality gives an indication of a node, based on how well they connect to a network (Rocha \& Masuda, 2014). Centrality has three main branches which include degree, betweenness and closeness centralities. This work will focus on degree and between-ness centralities. Degree Centrality is the number of links incident upon a node (i.e., the number of ties that a node has) (C. Li, Li, Van Mieghem, Stanley, \& Wang, 2015). The degree can be understood in terms of the instant possibility of a node for grasping whatsoever is rolling through the system. Degree Centrality often has two versions; in-degree which is the number of incoming links, or the number of predecessor nodes and out-degree which is the number of outgoing links, or the number of successor nodes (Samorodnitsky et al., 2016). Typically, we are interested in in-degree, since in-links are given by other nodes in the network, while out-links are determined by the node itself (Ohara, Saito, Kimura, \& Motoda, 2012). Between-ness centrality is the extent to which a node lies between on the shortest path to other nodes in a network (Zhang, Bao, Zhao, Chen, \& Tang, 2016). Nodes with high between-ness may have a substantial power within a network by an advantage of their control of material and resources transient between others. They are similarly the ones whose elimination from the network will most interrupt communications among other nodes because they lie on the biggest number of paths taken by messages. 


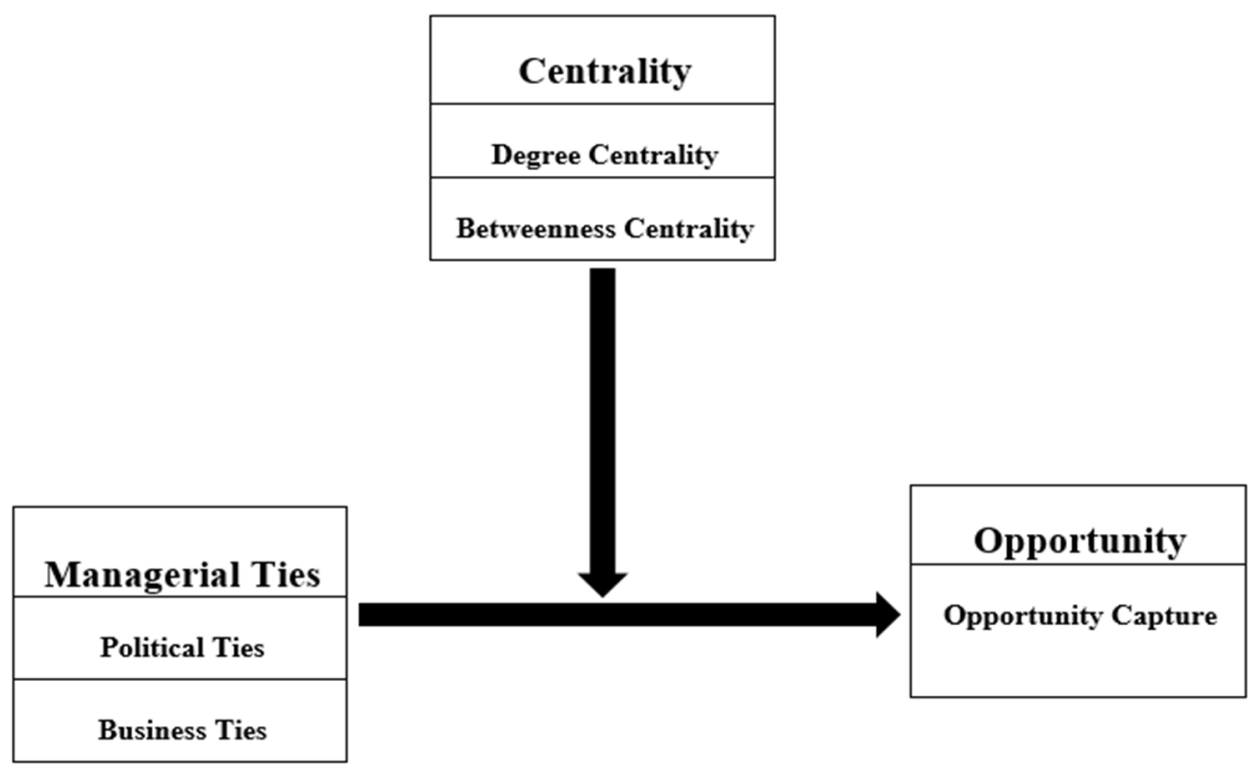

Figure 1: Conceptual Model (Figure 1, is the conceptual framework for this study. The group of managerial ties (Political and Business ties), are the independent variables and it shows they have a relationship with opportunity (opportunity capture). Managerial ties can pave the way to opportunities for SE. The Centrality encompasses degree and betweenness and they are represented as moderating variables in the frame. They moderate the relationship between managerial ties and opportunity).

This research encompasses the role political and business ties of social entrepreneurs play in aiding the entrepreneur grasp opportunities. This will be moderated by degree and between-ness centrality as can be seen in the model below.

\section{Hypothesis Development}

Social Entrepreneurs do not only build business ties (i.e., with managers at other firms) but also with government officials (i.e., government ties) for their network (Peng \& Luo, 2000). Conferring to the social network theory, government and business ties from networks help achieve access to certain scarce resources and information and reduce ambiguity (Li, J. J., Poppo, L., \& Zhou, 2008).

Ties with the government may be a relatively unique type of tie that entrepreneurs in an emerging economy especially like to cultivate (Peng \& Luo, 2000)because the government offers rare services which business ties can't. In most countries, especially developing countries, the government most a time holds the power to allocate strategic resources, approve projects, and to interfere in business operations. In these settings, political connections become a profitable way to lobby favors with government authorities (Teece, 2007). These favors could lead to or help in opportunity. Also, political connections play very vital roles in facilitating various types of exchanges in economies where formal institutional frameworks have not been well developed (Teece, 2007). Political legitimacy helps firms receive exclusive government endorsements and favorable treatment. With strong political ties, SE can turn to government officials to enforce business contracts which will favor them (Sheng et al., 2011), all of which may facilitate social entrepreneurs to quickly capture opportunities.

Hypothesis 1: Political ties positively affect opportunity capture

Business ties partners often work together in order to coordinate exchanges (D. Li, Eden, Hitt, \& Ireland, 2008). Through ties with other firms, firms not only gain resources and information similar to their existing business, but also gain novel information (such as technological changes) different from their existing business (Y. Li, Chen, Liu, \& Peng, 2014). Ties with other firms may broaden and deepen firms' market knowledge. These exchanges and acquired knowledge can lead to opportunity capture. Business ties help overcome the lack of resources because ties with other firms facilitate knowledge transfer, information sharing, and resource exchange (Teece, 2010). Consequently, SE may quickly respond to the changing societal conditions and gain valuable information from other SE that may present potentially great opportunities. These collaborations cultivate trust and mutual dependence between them. Such interpersonal norms limit their opportunistic behaviors and encourage long-term cooperation. This long-term cooperation often leads to opportunity capture.

Hypothesis 2: Business ties positively affect opportunity capture.

\subsection{Moderating Role of Degree and Betweenness Centrality}

Nurturing the progress of relations among various political ties in your network has qualitatively been proven that, the chances for collaborations and joint action increases (Bodin \& Crona, 2009). These collaborations enhance the 
exposure to new ideas and an increased amount of information. However, as a SE, being well-connected in a network involves having several members of the network being involved in other networks connections and as a result of this, a SE may suffer to discover and capture opportunities because their network members may not be available all the time to give them the necessary information and resources (Larcker, So, \& Wang, 2013). Furthermore, as political ties in a network can belong to other networks, this can lead to homogenization of information and knowledge which they share to their networks and this results in less efficient resource use and/or reduced capacities to adapt to changing conditions (Bodin \& Crona, 2009).

Hypothesis 3a: Degree centrality negatively moderates the relationship between political ties and opportunity capture.

Organizations interacting with one another through networks is very essential because these interactions help to discover new opportunities and obtain new knowledge which can help in capturing the discovered opportunities. Networks with many business ties permit organizations to access new knowledge from each other and may increase their efficiency through the dissemination of finest performances within institutions (Tsai, 2001). This fuels the SE innovative activities by providing the outside information necessary to produce novel concepts and capture opportunities.

Hypothesis 3b: Degree centrality positively moderates the relationship between business ties and opportunity capture.

When faced with unsuccessful administrative services, SE with closer political connections can solicit the power of their government connections to assist them (Danowski, 2015). As the entrepreneur lies between many political nodes, in seeking their assistance, the entrepreneur will have access to more services, information, and resources but it is necessary to know that government executives mostly pay attention to evolving their political careers, and they prefer to appease their supervisors, by not cooperating with firms such as SE (Y. Li et al., 2014). Also, government administrators prefer to focus more attention on prominent or large firms, which can considerably increase tax revenue. But most SE have little influence in their industry, and cannot afford a tax increase. More so, ties with the government imply that organizations must stand by government rules and failure to do so may lead to serious punishment. In most emerging economies, government officers alternate their positions across different sectors and geographic locations frequently, and this alternations often weakens or terminate a firm's political connections.

Hypothesis 4a: Between-ness centrality negatively moderates the relationship between political ties and opportunity creation.

The shortest paths to a node which characterizes between-ness centrality signify that the SE has the fastest connection to other nodes in the network compared to others. Hence, the SE is the most likely person to have quick and unencumbered access to the business ties in its network (Kelly, Athanassiou, \& Crittenden, 2000). Thus, in case of anything, they can easily contact many business ties within the shortest time possible. SE can use this closeness to capture and discover opportunities.

Hypothesis 4b: Between-ness centrality positively moderates the relationship between business ties and opportunity capture.

\section{Methodology}

\subsection{Sample and Study Instrument}

To examine our hypothesis, we selected social entrepreneurs from Yaounde, Douala, Bamenda, and Buea which represent the central, southern and western parts of Cameroon. We sampled these regions because, most entrepreneurs in Cameroon, have a long tradition of using managerial ties to facilitate their course. We selected a local senior manager (e.g., CEO, vice president, senior marketing manager) as the key informant because firms heavily rely on local managers for network building (Cusumano, Kahl, \& Suarez, 2008). To alleviate probable social desirability bias, respondents were informed in advance of the academic purpose of the project, the confidentiality of their responses, and that their responses would be used only in the collected analysis.

\subsection{Sampling Technique}

For this study, a mixed approach to collect data was used. Online questionnaires, as well as self-administered questionnaires, were used. Some face to face interviews were conducted as well. The original language for the questionnaire was English but it was translated to French for those who didn't understand English because Cameroon is a bilingual country having English and French as their official languages. For this purpose, a snowball sampling technique was used. It is a nonprobability selection technique where prevailing study subjects employ forthcoming subjects from among their contacts. Thus the sample set is said to develop like an evolving snowball. As the sample grows, sufficient statistics are collected to be suitable for research. A total of 300 questionnaires responses were recorded. 


\subsection{Surveys Structures}

The survey consisted of 4 parts. Section 1 was made up of questions representing control variables for demographic data such as age, sex, education level. Section 2 consisted of questions which focused on how managerial ties assist social entrepreneurs in discovering and capturing opportunities. Section 3 comprised of questions for the moderating effects of degree and betweenness centrality. And section 4 on Opportunity capture. A five-point Likert Scale, with Strongly Agreed (5), Agreed (4), Neutral (3), Disagreed (2), and Strongly Disagreed (1), was used to measure the 15 items (Likert, 1932). Survey questions were developed by the authors of this study and ideas were also gotten from other researchers such as (Y. Li et al., 2014).

\subsection{Sample Measure}

\subsubsection{Political Ties}

Political ties for this study refers to the relationship or link a social entrepreneur has with government officials that can help them in acquiring opportunities. It can either be the local, state, national or federal government. The items used to measure this construct were lent from Zheng et al., (2017). This is to answer how political ties lead to opportunity. Also, items from Sheng, Zhou, \& Julie Juan Li (2011), will be used to measure how political ties affect for opportunity capture.

\subsubsection{Business Ties}

Business ties in this research, states the connection a social entrepreneur has with any organization apart from government. Business ties could include NGOs, banks, international organizations, entrepreneurs and so on. The measurement pieces for this were gotten from D. Li, Eden, Hitt, \& Ireland (2008), Teece (2010), to respond to how business ties lead to opportunity capture.

5.4.3 Degree Centrality

Degree centrality refers to the number of ties a node (actor) has to other actors in a network (C. Li et al., 2015). This gives the social entrepreneur significant exposure to the network and the S.E can directly influence other actors in the network. To measure this, items were gotten from Bodin \& Crona (2009) and Tsai (2001) to show how SE can influence government ties in collaborating and having joint actions on one hand, and on the other hand how business ties allow organizations to access new knowledge from each other and may increase their efficiency through dissemination of "best practices" within organizations. The aforementioned is to measure how degree centrality between managerial ties and social entrepreneur can affect for opportunity capture.

5.4.4 Between-ness Centrality

Between-ness centrality is the degree to which a node lies between on the shortest path to other nodes in a network (Zhang et al., 2016). In this study, Between-ness centrality focuses on the extent to which a SE serves as an intermediary that facilitates the flow of resources between other entrepreneurs in the network, reflecting the notion that gatekeeping positions provide an entrepreneur with a unique ability to monitor and control resource flows (Neal, 2011). And items from Neal (2011), will be used to measure how between-ness centrality amongst managerial ties and SE can affect for opportunity capture.

\subsubsection{Opportunity}

Opportunity can be defined as a time or set of conditions that makes it potential to do something. According to Eckhardt \& Shane, (2003), entrepreneurial opportunities are seen as circumstances in which new goods and services, as well as raw materials, are presented by creating new methods to meet up with demand. Furthermore, "Current conceptualizations of social entrepreneurial opportunity share a focus on the relevance of stakeholders for the ... three dimensions that lead to social entrepreneurial opportunities: 1) activism by those who hold social concern; 2) help from beneficiaries of the social enterprise and; 3) philanthropic donations by those who support the mission of the social venture. Each of those three dimensions depends on the active participation of resource holding stakeholders." (McDermott, Kurucz, \& Colbert, 2018). This ties very much with this study as we try to see how managerial ties assist social entrepreneurs in discovering and capturing opportunities.

Thus, social entrepreneurs have to facilitate the mobilization of resources needed for an opportunity by encouraging sponsors in their networks who are not convinced to see reason with them. So social entrepreneurs have to bring their ties together and conglomerate assets to tackle a social issue(McDermott et al., 2018).

\section{Measurement analysis}

The analysis factor for this research was conducted using SPSS version 23.0 to analyze the original structure of the constructs. To ensure that the variables do relate to one another enough to run a meaningful exploratory factor analysis, the principal analysis method was to analyze the reliability of each variable. Reliability and validity were the main constructs used for this study. The assessment of the entire relationships was done by the following: reliability and validity: The Cronbach alpha $(\alpha)$ was used for this study. It was used to assess the variables reliability average variance with the threshold of $>.70$ to show its associations with other constructs (Peterson, 2013). Another model is the discriminant validity by Fornell-Lacker's criterion is used to confirm the variables in the model. The authors determined the R-Square $\mathrm{R}^{2}$, effect size $\left(\mathrm{f}^{2}\right)$, Path Coefficient ( $\mathrm{t}$-value), and these were used 
to ascertain the correlational affirmation of the variables.

\section{Results}

The standard for social science(IBM, 2015) reliability and validity indicate that the variables measured should have a crobanch alpha which equal to or $>0.7$. The Cronbach $\alpha$ value for of Government Ties (GT) summed up to .807 . That of Business Ties (BT) is .802. Degree Centrality (DC) gave a Cronbach $\alpha$ of .810. The Cronbach $\alpha$ value of Betweenness Centrality (BC) is .800. That of Opportunity Capture is .787. The total Cronbach Alpha of the work is .768. All the variables are $>.70$ indicating reliability criteria.

To avoid the danger multicollinearity, all the variables were mean-centered in equations that included the interaction terms (Aiken \& West, 1991).

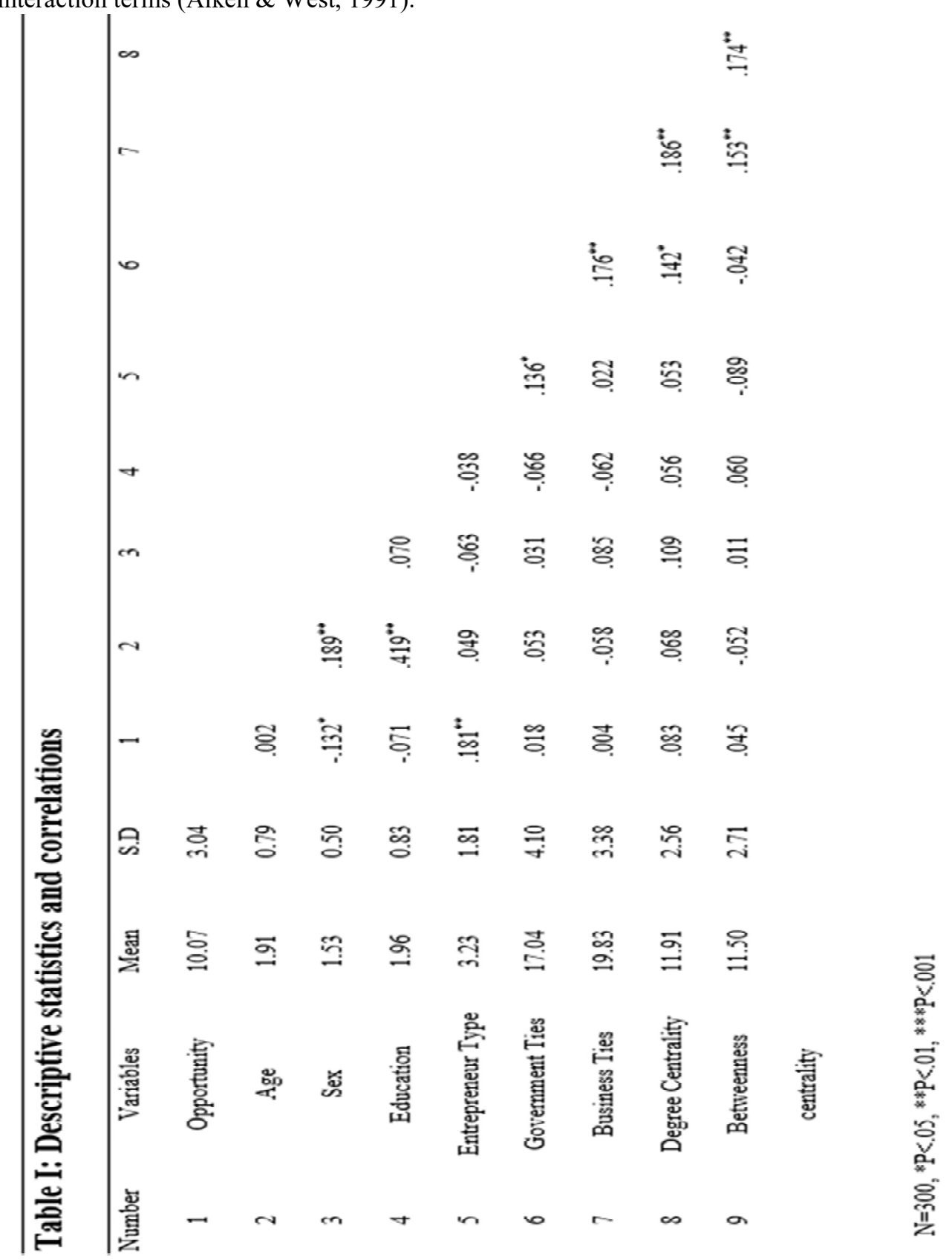

\subsection{Main effects}

Hypothesis 1 envisages that government ties have a positive influence on opportunity capture. In Table 2 , the results shown in Model 1 illustrates that the effect is negative $(\beta-0.009, p<.001)$. Model 3 shows the effects of business ties and this explains hypothesis 2 which states that business ties have a positive effect on opportunity capture $(\beta 0.009, \mathrm{p}<.01)$. Still, in Table 2 , Model 1 provides the starting point results for the effects of the control variables. Therefore, hypothesis 1 is rejected and hypothesis 2 is supported. 
Table II. Standardized coefficient estimates: multiple moderated regressions

\begin{tabular}{|c|c|c|c|c|c|c|}
\hline \multirow[t]{2}{*}{ Variables } & \multicolumn{6}{|c|}{ Opportunity Capture } \\
\hline & Model 1 & Model 2 & Model 3 & Model 4 & Model 5 & Model 6 \\
\hline \multicolumn{7}{|l|}{ Controls } \\
\hline Age & $.049 *$ & $.050 *$ & $.050 *$ & $.048 *$ & .059 & 0.57 \\
\hline Gender & $-.125^{*}$ & $-.125^{*}$ & $-.126^{*}$ & $-.134 *$ & $-.126^{*}$ & $-.133 *$ \\
\hline Education & $-.077 *$ & $-.078^{*}$ & $-.077 *$ & $-.083 *$ & $-.088^{*}$ & $-094 *$ \\
\hline Entrepreneurial & $.168 * * *$ & $.169 * * *$ & $.168 * * *$ & $.165 * * *$ & $.189 * * *$ & $.186 * * *$ \\
\hline \multicolumn{7}{|l|}{ Institution } \\
\hline \multicolumn{7}{|l|}{ Predictors } \\
\hline Government Ties H1 & & $-.009 * * *$ & & $-.020 * *$ & $.002 * *$ & $-.007 * * *$ \\
\hline Business Ties H2 & & & $.009 * *$ & $-.004 * * *$ & $.027 *$ & $.018^{*}$ \\
\hline \multicolumn{7}{|l|}{ Moderators } \\
\hline Degree Centrality (DC) & & & & $.094 * * *$ & & $.081 * * *$ \\
\hline Betweenness & & & & & $.060 * * *$ & $.043^{*}$ \\
\hline \multicolumn{7}{|l|}{ Centrality (BC) } \\
\hline \multicolumn{7}{|l|}{ Interactions } \\
\hline Government ties x DC H3a & & & & $-.006 * * *$ & & $-.002 * * *$ \\
\hline Business ties x DC H3b & & & & $.010 * *$ & & $-.049 * *$ \\
\hline Government ties x BC H4a & & & & & $-.069^{*}$ & $-.057^{*}$ \\
\hline Business ties $\times \mathrm{BC} \mathrm{H} 4 \mathrm{~b}$ & & & & & $.150 * * *$ & $.169 * * *$ \\
\hline \multicolumn{7}{|l|}{ Test Results } \\
\hline R-square & .052 & .053 & 0.53 & .061 & .077 & .084 \\
\hline Adjusted $\mathrm{R}^{2}$ & .040 & .036 & 0.36 & .032 & .048 & .046 \\
\hline Model F & 4.083 & 3.261 & 3.261 & 2.098 & 2.673 & 2.207 \\
\hline Model df & 4 & 5 & 5 & 9 & 9 & 12 \\
\hline$\Delta \mathrm{R}^{2}$ & & .007 & & .030 & .005 & .012 \\
\hline
\end{tabular}

$\mathrm{N}=300, * \mathrm{P}<.05, * * \mathrm{P}<.01, * * * \mathrm{P}<.001$

\subsection{Moderating effects}

Hypothesis 3 predicts the moderating effects of degree centrality on government and business ties to opportunity capture. Model 4 shows that degree centrality has a positive significance $(\beta 0.094, p<.001)$. It further reveals that degree centrality has a negative effect on government ties $(\beta-0.006, p<.001)$ and a positive effect on business ties $(\beta 0.010, p<.01)$ hence supporting hypothesis $3 \mathrm{a}$ and $3 \mathrm{~b}$. In hypothesis 4 , we look at the effects of betweenness centrality on both government and business ties to opportunity capture. Model 5 tells that, betweenness centrality has a positive significance $(\beta 0.060, \mathrm{p}<.001)$. Also, it makes known that betweenness centrality negatively affects government ties $(\beta-0.069, \mathrm{p}<.001)$ and has betweenness centrality positively affects business ties $(\beta 0.150, \mathrm{p}$ $<.001)$ thus hypothesis $4 \mathrm{a}$ and $4 \mathrm{~b}$ are sustained.

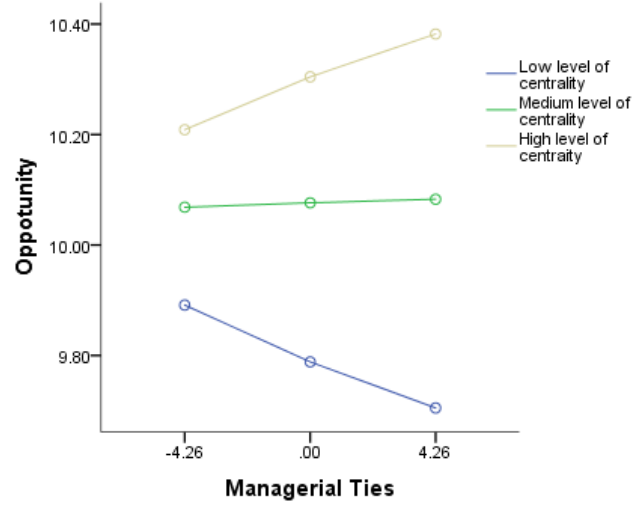

Figure 2: Moderation Effect of Degree and Betweenness Centrality (Using the processmacro by Hayes, we were able to do a graphical representation of the various levels of the moderators. The high, medium and low level of degree and betweenness centrality in our study).

\section{Discussions}

Social entrepreneurship is an important phenomenon to boost in most developing countries. Social entrepreneurial knowledge is essential to build skills and experience and funding for such social interventions can be gotten through business persons, governments, philanthropists, and it requires social network ties for smooth 
programming.

\subsection{Contributions}

The relationship between managerial ties, centrality and opportunity capture in an emerging economy is scouted by our conceptual model. This research develops research on SE opportunity capture by relating the social network theory as the central framework. Our results show that managerial ties as important social capital have an influence on opportunity capture, and centrality can influence the efficacy of managerial ties' impact on opportunity capture. Specifically, our study offers three important contributions to social entrepreneurship and centrality literature.

The first contribution of this study is constructing a connection between social entrepreneurs, managerial ties and opportunity capture. This study shows that SE can receive different assistance from government and business ties which can help them grasp opportunities. Looking at the effects of managerial ties from the gotten results, it tells that business ties are more efficient and reliable than government ties in opportunity capture. Unlike previous research, (Sheng et al., 2011) which says strong government support can reduce the efficiency of business ties which supported the first hypothesis, this study rather puts forward the opposite. This is because, in social entrepreneurship business ties network, they know each other well enough that they can give references to colleagues for aid. This network builds trust and confidence between the persons of the group and goes a long way to develop one another. This findings go ahead to debunk hypothesis 1 and support hypothesis 2 .

Secondly, the political system also may inhibit firm performance. In many developing countries, most government officials have to rotate their positions across different geographical zones of the country. As a result of this, the efficacy of government ties on opportunity tend to drop and in turn, social entrepreneurs should abstain from political networks and rather depend more on business networks, which still can foster opportunity (Sheng et al., 2011). From this, we see reasons why our findings put forward that government ties negatively affect opportunity capture. In relation to our proposition, most social entrepreneurs now rely more on networking among themselves (Balfour 2007).

Finally, this research introduces the aspect of centrality to moderate the link between managerial ties and opportunity. This is a step toward theoretically integrating social

Network in our framework. We used degree and betweenness centrality to moderate the relationship between government and business ties towards opportunity and we noticed the different effects they portrayed. Grounded by the results, it is suggested that, SE are cheered to devise focus on degree and betweenness centrality in their network with business ties as this has a positive effect on opportunity capture. This tallies with both hypothesis 3 and 4. Because degree and betweenness centrality positively and negatively moderates the relationship between business and government ties on opportunity capture respectively, SE tend to focus their attention more on business ties. Having a great degree and between-ness centrality in your business network will eventually lead to opportunity capture.

\subsection{Managerial Implication}

Our findings provide some vital managerial implications for social entrepreneurs and opportunity capture. In connection with the theory and data analyzed, it is important for social entrepreneurs in Cameroon to note that building ties with government and business are important for opportunity capture because they provide different services. However, building more business ties in a network can significantly improve on opportunity capture than government ties as our results show negative effects of government ties on opportunity capture.

In the meantime, our results annotate that centrality can foster the process of opportunity capture in SE. SE have to select an appropriate centrality type that matches a particular form of managerial ties. Precisely, SE who want to discover and capture opportunities through business ties are encouraged to engage more in degree and betweenness centrality. On the other hand, SE who still want to discover and capture opportunities are not encouraged to do so via government ties. In General, our study provides SE with an efficient way to manage the capture of opportunity process through managerial ties and degree and betweenness centrality of an emerging economy.

\subsection{Limitations}

Despite the contributions made by this research, there are a few limitations faced by this study. The first limitation is that the study focuses on one country. It is thus proposed that additional research on the same study can be carried out in other developing countries because they have similarities. This will go a long way to add to existing literature on entrepreneurship, SE, and opportunity.

Secondly, this research centers on managerial ties and opportunity. The liaison between managerial ties and opportunity capture. Further research can look at other factors such as environment, social capital that can enable Social Entrepreneurs to discover and capture opportunities.

Thirdly, we show that business ties both have positive effects on opportunity capture, unlike government ties. Future research can do a comparison on the two ties and how they affect an opportunity for social entrepreneurs 
separately showing both positive and negative effects.

\section{Conclusion}

This study demonstrates that managerial ties of social entrepreneurs have a very important effect when it comes to opportunity capture. They help the entrepreneurs directly or indirectly to grasp opportunities. Also, centrality (between-ness and degree) is introduced to moderate this relationship. The results gotten from this study gives a significant implication for SE to follow in order to discover and capture more opportunities. Finally, a lot needs to be done to strengthen the environment for social entrepreneurship in developing countries, as this is an essential ground for generating profitable, social and environmental opportunity for citizens across the globe.

\section{References}

Aiken, L. S., \& West, S. G. (1991). Multiple Regression: Testing and interpreting Interactions. Newbury Park, CA: Sage.

Austin, J., Stevenson, H., \& Wei-Skillern, J. (2006). Social and Commercial Entrepreneurship: Same, Different, or Both? Entrepreneurship Theory and Practice, (30), 1-22. Retrieved from https://onlinelibrary.wiley.com/doi/pdf/10.1111/j.1540-6520.2006.00107.x

Bodin, Ö., \& Crona, B. I. (2009). The role of social networks in natural resource governance: What relational patterns make a difference? Global Environmental Change, 19(3), 366-374. https://doi.org/10.1016/j.gloenvcha.2009.05.002

Bornstein, David, and S. D. (2010). Social Entrepreneurship: What Everyone Needs to Know. Oxford University Press. Retrieved from https://s3.amazonaws.com/academia.edu.documents/40545977/SocialEntrepreneurship-What-Everyone-Needs-to-Know-Teaching-notes-

final.pdf?AWSAccessKeyId=AKIAIWOWYYGZ2Y53UL3A\&Expires=1533784431\&Signature=nVln0an grEI3qZlwxdzTVOWB3oo\%3D\&response-content-disposit

Brooks, A. C. (2008). Social entrepreneurship. A modern approach to social value creation. Retrieved from http://www.gbv.de/dms/zbw/566652404.pdf

Caliendo, M., \& Kritikos, A. S. (2010). Start-ups by the unemployed: Characteristics, survival and direct employment effects. Small Business Economics, 35(1), 71-92. https://doi.org/10.1007/s11187-009-9208-4

Chen, M. H., Chang, Y. Y., \& Lee, C. Y. (2015). Creative entrepreneurs' guanxi networks and success: Information and resource. Journal of Business Research, 68(4), 900-905. https://doi.org/10.1016/j.jbusres.2014.11.049

Cusumano, M. A., Kahl, S. j, \& Suarez, F. F. (2008). Services, industry evolution, and the copetitive strategies of product firms. Academy of Management Journal, 51(2), 315-334. https://doi.org/10.1002/smj

Danowski, A. (2015). The Politics of Social Entrepreneurship in Cameroon The Politics of Social Entrepreneurship in Cameroon.

Driver, M., Porter, M., \& Lawrence, B. W. (2012). An Interview With Michael Porter : Social Entrepreneurship and the. Academy of Management Learning \& Education, 11(3), 421-431. https://doi.org/10.5465/amle.2011.0002

Eckhardt, J. T., \& Shane, S. A. (2003). Opportunities and entrepreneurship. Journal of Management, 29(3), 333349. https://doi.org/10.1016/S0149-2063(02)00225-8

El Ebrashi, R. (2013). Social entrepreneurship theory and sustainable social impact. Social Responsibility Journal, 9(2), 188-209. https://doi.org/10.1108/SRJ-07-2011-0013

Geletkanycz, M. A., \& Hambrick, D. C. (1997). The External Ties of Top Executives: Implications for Strategic Choice and Performance. Administrative Science Quarterly, 42(4), 654. https://doi.org/10.2307/2393653

Ghose, R., \& Pettygrove, M. (2014). Actors and networks in urban community garden development. Geoforum, 53, 93-103. https://doi.org/10.1016/j.geoforum.2014.02.009

IBM. (2015). SPSS Software. Predictive Analytics Software and Solutions, 1.

Jenvey, N. (2015). The global rise of social entrepreneurship. Retrieved from http://www.universityworldnews.com/article.php?story=20150324131055167

Kelly, L. M., Athanassiou, N., \& Crittenden, W. F. (2000). Founder centrality and strategic behavior in the familyowned firm. Entrepreneurship Theory and Practice, (Winter), 27-42. https://doi.org/10.1177/104225870002500202

Larcker, D. F., So, E. C., \& Wang, C. C. Y. (2013). Boardroom Centrality and Firm Performance. Journal of Accounting \& Economics, 225-250. Retrieved from http://nrs.harvard.edu/urn-3:HUL.InstRepos:28548030

Li, J. J., \& Zhou, K. Z. (2010). How foreign firms achieve competitive advantage in the Chinese emerging economy: Managerial ties and market orientation. Journal of Business Research, 63(8), 856-862. Retrieved from http://citeseerx.ist.psu.edu/viewdoc/download?doi=10.1.1.604.9578\&rep=rep1\&type=pdf

Li, J. J., Poppo, L., \& Zhou, K. Z. (2008). Do managerial ties in China always produce value? Competition, uncertainty, and domestic vs. foreign firms. Strategic Management Journal, 29(4), 383-400. Retrieved from https://onlinelibrary.wiley.com/doi/pdf/10.1002/smj.665 
Li, C., Li, Q., Van Mieghem, P., Stanley, H. E., \& Wang, H. (2015). Correlation between centrality metrics and their application to the opinion model. European Physical Journal B, 88(3), 1-13. https://doi.org/10.1140/epjb/e2015-50671-y

Li, D., Eden, L., Hitt, M. A., \& Ireland, R. D. (2008). Friends, acquaintances, or strangers? Partner selection in R\&D alliances. Academy of Management Journal, 51(2), 315-334. https://doi.org/10.5465/AMJ.2008.31767271

Li, Y., Chen, H., Liu, Y., \& Peng, M. W. (2014). Managerial ties, organizational learning, and opportunity capture: A social capital perspective. Asia Pacific Journal of Management, 31(1), $271-291$. https://doi.org/10.1007/s10490-012-9330-8

Likert, R. (1932). A technique for the measurement of attitudes. Archives of Psychology. https://doi.org/2731047

Liu, W., Sidhu, A., Beacom, A. M., \& Valente, T. W. (2017). Social Network Theory. In The International Encyclopedia of Media Effects (pp. 1-12). https://doi.org/10.1002/9781118783764.wbieme0092

McDermott, K., Kurucz, E. C., \& Colbert, B. A. (2018). Social entrepreneurial opportunity and active stakeholder participation: Resource mobilization in enterprising conveners of cross-sector social partnerships. Journal of Cleaner Production, 183, 121-131. https://doi.org/10.1016/j.jclepro.2018.02.010

McGrath, R. G. (1995). Advantage from adversity: Learning from disappointment in internal corporate ventures. Journal of Business Venturing, 10(2), 121-142. https://doi.org/10.1016/0883-9026(94)00021-L

Neal, Z. (2011). Differentiating Centrality and Power in the World City Network. https://doi.org/10.1177/0042098010388954

Nieto, M., \& González-Álvarez, N. (2016). Social capital effects on the discovery and exploitation of entrepreneurial opportunities. International Entrepreneurship and Management Journal, 12(2), 507-530. https://doi.org/10.1007/s11365-014-0353-0

Ohara, K., Saito, K., Kimura, M., \& Motoda, H. (2012). Effect of in/out-degree correlation on influence degree of two contrasting information diffusion models. In Lecture Notes in Computer Science (including subseries Lecture Notes in Artificial Intelligence and Lecture Notes in Bioinformatics) (Vol. 7227 LNCS, pp. 131-138). https://doi.org/10.1007/978-3-642-29047-3_16

Peng, M. W., Lee, S. H., \& Hong, S. J. (2014). Entrepreneurs as intermediaries. Journal of World Business, 49(1), 21-31. https://doi.org/10.1016/j.jwb.2013.04.003

Peng, M. W., \& Luo, Y. (2000). Managerial ties and firm performance in a transition economy: The nature of a micro-macro link. Academy of Management Journal, 43(3), 486-501. https://doi.org/10.2307/1556406

Peterson, R. A. (2013). Meta-analysis of Alpha Cronbach â€ $\mathrm{TM}_{\mathrm{T}}^{\mathrm{TM}}$ Coefficient. Journal of Consumer Research, 21(2), 381-391. https://doi.org/10.1093/bioinformatics/btr476

Pozen, D. E. (2008). We are all entrepreneurs now. Wake Forest Law Review, 43, 283.

Pruthi, S. (2014). Social ties and venture creation by returnee entrepreneurs. International Business Review, 23(6), 1139-1152. https://doi.org/10.1016/j.ibusrev.2014.03.012

Ramoglou, S., \& Tsang, E. W. K. (2016). A realist perspective of entrepreneurship: Opportunities as propensities. Academy of Management Review. https://doi.org/10.5465/amr.2014.0281

Rocha, L. E. C., \& Masuda, N. (2014). Random walk centrality for temporal networks. New Journal of Physics, 16. https://doi.org/10.1088/1367-2630/16/6/063023

Samorodnitsky, G., Resnick, S., Towsley, D., Davis, R., Willis, A., \& Wan, P. (2016). Nonstandard regular variation of in-degree and out-degree in the preferential attachment model. Journal of Applied Probability, 53(1), 146-161. https://doi.org/10.1017/jpr.2015.15

Shane, S. (2012). Reflections on the 2010 AMR decade award: Delivering on the promise of entrepreneurship as a field of research. Academy of Management Review, 37(1), 10-20. https://doi.org/10.5465/amr.2011.0078

Sheng, S., Zhou, K. Z., \& Julie Juan Li. (2011). The Effects of Business and Political Ties on Firm Performance: Evidence from China. Journal of Marketing, 75(January), 1-15. https://doi.org/10.2307/25764291

Short, J. C., Ketchen Jr, D. J., Shook, C. L., \& Ireland, R. D. (2010). The concept of "opportunity" in entrepreneurship research: Past accomplishments and future challenges. Journal of Management, 36(1), 4065. Retrieved from https://www.researchgate.net/profile/Jeremy_Short/publication/240249110_The_Concept_of_Opportunity in_Entrepreneurship_Research_Past_Accomplishments_and_Future_Challenges/links/56364cb308ae88cf81 bd10de.pdf

Strobl, A. (2014). What ties resources to entrepreneurs? - activating social capital. International Journal of Entrepreneurial Venturing, 6(2), 140-161. https://doi.org/10.1504/IJEV.2014.062749

Suddaby, R., Bruton, G. D., \& Si, S. X. (2015). Entrepreneurship through a qualitative lens: Insights on the construction and/or discovery of entrepreneurial opportunity. Journal of Business Venturing, 30(1), 1-10. https://doi.org/10.1016/j.jbusvent.2014.09.003

Teece, D. J. (2007). Explicating dynamic capabilities: The nature and microfoundations of (sustainable) enterprise performance. Strategic Management Journal, 28(13), 1319-1350. https://doi.org/10.1002/smj.640 
Teece, D. J. (2010). Business models, business strategy and innovation. Long Range Planning, 43(2-3), $172-194$. https://doi.org/10.1016/j.lrp.2009.07.003

Tsai, W. (2001). Knowledge Transfer in Intraorganizational Networks: Effects of Network Position and Absorptive Capacity on Business Unit Innovation and Performance Wenpin Tsai KNOWLEDGE TRANSFER IN INTRAORGANIZATIONAL NETWORKS : EFFECTS OF NETWORK POSITION AND ABSORPTIV. The Academy of Management Journal, 44(5), 996-1004. https://doi.org/10.2307/3069443

Zhang, Y., Bao, Y., Zhao, S., Chen, J., \& Tang, J. (2016). Identifying Node Importance by Combining Betweenness Centrality and Katz Centrality. In Proceedings - 2015 International Conference on Cloud Computing and Big Data, CCBD 2015 (pp. 354-357). https://doi.org/10.1109/CCBD.2015.19

Zheng, W., Singh, K., \& Chung, C. N. (2017). Ties to Unbind: Political Ties and Firm Sell-Offs During Institutional Transition. Journal of Management, 43(7), 2005-2036. https://doi.org/10.1177/0149206315575553

Zhou, K. Z., Li, J. J., Sheng, S., \& Shao, A. T. (2014). The evolving role of managerial ties and firm capabilities in an emerging economy: evidence from China. Journal of the Academy of Marketing Science, 42(6), 581595. https://doi.org/10.1007/s11747-014-0371-z

\section{Acknowledgement}

We will like to thank the University of Science and Technology of China for granting me an opportunity to pursue studies in their institution, and I'll also want to thank the China Scholarship Council (CSC) for financing our studies. 